\title{
The Olympic Games and the economic performance of the host city - the case of London 2012 against selected global cities
}

Julia Jastrząbek*

\section{Introduction}

Since the revival of the Olympic Games in 1896, how they are organised has been associated with a city designated to host the most hallmark sporting mega-event worldwide. Staging the Olympics can bring international renown to the city and create an opportunity to showcase its best advantages. Cities interested in hosting the event try to estimate the socioeconomic effects before they decide whether to bid for the Games. Organising the Olympic Games is frequently treated as a catalyst of urban change (Essex \& Chalkley 1998), not only in terms of constructing sports facilities, but also in improving urban spaces, road networks, rail links, public transport, and much more. Thanks to these numerous projects required for staging the Olympics, it is expected that the host city will experience a construction boost, a reinvigoration of urban areas or an inflow of investment and tourists. However, previous experiences of host cities indicate that the socioeconomic impact of the Olympics is still ambiguous, leaving the city with underused facilities and drained budgets. These problems are just a small sample of the many challenging issues, and they are one of the reasons for the recent downward trend of cities interested in bidding to host the Olympic event. ${ }^{1}$

\footnotetext{
* Julia Jastrząbek - magister, Uniwersytet Ekonomiczny w Poznaniu, Instytut Ekonomii, julia.jastrzabek@ue.poznan.pl

${ }^{1}$ For the 2012 Summer Olympic Games, there were nine bids (applicant cities) from which five candidate cities were selected, whereas for the 2024 edition, only two cities were left in the race - Paris and Los Angeles - after earlier withdrawals by Hamburg, Rome and Budapest. Both cities submitted very strong bids with the Games concept, thus, the IOC made the unprecedented decision to award the 2024 Olympic Games to Paris and the 2028 Games to Los Angeles simultaneously.
} 
In this article, the research focus is concentrated on London - the host city of the 2012 Summer Olympic Games. The UK capital used the Olympics as a tool for complex urban regeneration by implementing a transformative and legacy-leaving agenda into urban and socioeconomic space in the most disadvantaged boroughs in East London (Roche 2017, p. 255). Given the Olympic context, London placed its aspirations on seeking a stimulus for the city's economy and to elevate its position among global cities. There are two main research aims of this paper. The first one is to evaluate London's post-event legacy based on a critical literature review. The second research goal is to assess London's economic performance based on selected economic indicators by comparing London as the Olympic host city with reference groups of global cities.

The time span of this research covers 2005-2018 and is divided into the following time intervals: the Pre-Games phase, the Games phase and the PostGames phase. The beginning of the adopted time span was dictated by the date of London's selection as the host for the 2012 Games, while the end was mainly determined by data availability.

The paper is structured as follows. It begins with a concise literature review on the notion of the impact and legacy of the Olympic event, underlining the differences between these two terms in examining the Olympic Games effects on host cities. In the second section, the author evaluates the 2012 London Olympic Games' socioeconomic and urban impacts from a literature review. The third section presents an empirical analysis including a series of figures with macroeconomic indicators such as real GDP growth rate and unemployment rate, as well as basic descriptive statistics in order to accentuate the dynamics of London's economic performance against comparative groups of cities. The concluding remarks comprise a summary of the results from statistical analysis and present the author's evaluation of London's legacy derived from hosting the Olympics.

\section{The impact and legacy of the Olympic mega-event on host cities - a literature review}

Impact and legacy are among the key reasons why cities express an interest in staging global sporting mega-events such as the Olympic Games or the Football World Cup. Social, economic or urban impact studies of the Olympic Games have become prevalent, particularly since the 1984 Summer Olympic Games in Los Angeles (Kasimati 2003, p. 434). Following this event, which showed that the Olympics could turn a profit (Andranovich et al. 2001, p. 124), economic impact studies aimed at examining the potential effects from staging the Olympics have 
developed as an integral part of each Games edition. The term impact more notably relates to short-term effects that derive from organising the Olympic Games. The impact studies mostly take the form of ex-ante or ex-post quantitative analyses that are related to economics (Gratton \& Preuss 2008, p. 1925). However, especially over the last four decades, an increasing range of operations, investments, activities and costs inextricably linked with the Olympics have been observed. Therefore, in order to embrace the long-term character of tangible and intangible impacts fostered by organising the Olympic Games, the concept of legacy has been widely adopted.

Since the 1990s, the concept of legacy has been disseminated and, as a consequence, academic interest and research in this area have increased considerably (Preuss 2007, p. 208). Over the years, several definitions of legacies have been developed, alongside in-depth studies that characterise their positive and negative aspects. For example, Furrer (2002) defines the Olympic legacy as physical, economic, environmental, social, cultural, psychological, political or even ideological impacts, combined with the concept of sustainable development, which indicates how staging Olympic event can contribute to sustainability in the urban milieu (pp. 2-3). Preuss (2007) conceptualises legacy as "all planned and unplanned, positive and negative, tangible and intangible structures created for and by a sport event that remain longer than the event itself, irrespective of the time of production and space" (p. 211). Chappelet (2012) adds another dimension of legacy concerning its material, territorial and sporting nature (p. 78), while Cashman (2006, as cited in Preuss 2007, p. 210) categorises legacies on six fields: (1) sport; (2) economics; (3) infrastructure; (4) information and education; (5) public life, politics and culture; and (6) symbols, memory and history. The International Olympic Committee's (2017) official definition of legacy is: "Olympic legacy is the result of a vision. It encompasses all the tangible and intangible long-term benefits initiated or accelerated by the hosting of the Olympic Games/sport events for people, cities/territories and the Olympic Movement" (p. 2).

The Olympic event in host cities is perceived as a catalyst of major urban change (Essex \& Chalkley 1998). Once a city becomes the Olympic host, it is identified as an 'Olympic city', thus acquiring stronger image value, city branding, an investment boost and global recognition among foreign tourists and investors. These effects are in line with the concept of a 'global city' (Sassen 2005), and the Olympic bid process can be perceived as an illustration of what may be understood as 'a competitive global city' (Tolzmann 2014). An interest in staging the Olympics is also prompted by efforts to strengthen a city's global status in growing inter-urban competition and deliver large-scale construction projects (Shoval 2002, p. 583). 
Table 1. Selected positive and negative impacts and legacies of staging the Olympic Games

\begin{tabular}{|c|c|c|}
\hline & Positive & Negative \\
\hline Tangible & $\begin{array}{l}\text { - Increase in sport participation, } \\
\text { - New world-class sports venues, } \\
\text { - Urban regeneration (new public } \\
\text { spaces, infrastructure, transport } \\
\text { improvements), } \\
\text { - New job opportunities, } \\
\text { - Increased tourism during and after } \\
\text { the event, } \\
\text { - Better environmental conditions, } \\
\text { - Real estate growth, } \\
\text { - Improved tourism facilities and } \\
\text { - Bccommodation base, } \\
\text { - Benefits for local merchants and } \\
\text { entrepreneurs, } \\
\text { - New environmental principles of } \\
\text { design, recycling, renewable ener- } \\
\text { gy sources, emphasis on providing } \\
\text { 'sustainable Games'. }\end{array}$ & $\begin{array}{l}\text { - Local debt due to over-investment, } \\
\text { - High costs, } \\
\text { - Temporary nature of extra jobs and } \\
\text { economic activities, } \\
\text { - Decreased social subsidies (money } \\
\text { transferred towards Olympic invest- } \\
\text { ments, not to residents), } \\
\text { - Rising costs of living, } \\
\text { - Unnecessary facilities (white elephants), } \\
\text { - Tax increases to cover additional ex- } \\
\text { penses, } \\
\text { - Displacements and evictions of city } \\
\text { residents. }\end{array}$ \\
\hline Intangible & $\begin{array}{l}\text { - Increased reputation and interna- } \\
\text { tional recognition among potential } \\
\text { investors or tourists, } \\
\text { - Promotion of host city, } \\
\text { - Experience and know-how, } \\
\text { - Enhanced sense of community and } \\
\text { self-worth, } \\
\text { - Image and identity, national proud, } \\
\text { - Education through sport, } \\
\text { - Greater civic sense. }\end{array}$ & $\begin{array}{l}\text { - Social opposition against the Olympic } \\
\text { - Eames, } \\
\text { - Event 'politicisation', } \\
\text { - Decrease in international reputation due } \\
\text { to, e.g. construction delays or organisa- } \\
\text { tional setbacks, } \\
\text { - Olympic investments vs. public needs } \\
\text { dilemma, } \\
\text { - Concerns among local entrepreneurs } \\
\text { about increased competition from global } \\
\text { businesses, } \\
\text { - Transportation problems due to } \\
\text { traffic reorganisation in host city and } \\
\text { over-crowding, } \\
\text { - Social injustices. }\end{array}$ \\
\hline
\end{tabular}

Source: compiled from Chen et al. 2013, p. 3; Open Economics \& CEIS-Tor Vergata 2013, p. 67-68; Scandizzo \& Pierleoni 2018, p. 6; Zawadzki 2017, p. 65.

However, taking into consideration the number of negative impacts caused by the Olympics (see also Table 1), the IOC, as the owner of Olympic Games, has recently suffered a major crisis, i.e., the declining number of cities willing to bid for the event. To restore the Olympic Games status as an attractive source of long-lasting positive legacies for cities, the Olympic Agenda 2020 and The New Norm documents were implemented. The Olympic Agenda 2020 includes 40 recommendations aimed at, among others, reducing costs and organisational risks as well as maximising positive legacies for candidate and host cities (IOC 2014). 
The New Norm focuses on six recommendations ${ }^{2}$ related to organising the Games to meet long-term development goals in cities, provide more assistance from the IOC and Olympic Movement, and help the Olympics to be more sustainable, beneficial and financially viable (IOC 2018).

Various empirical studies examining the socioeconomic impact of the Olympic Games not only focus on the local economy, but they also evaluate this stimulus at the regional or national level. Table 2 shows a sample of studies on the socioeconomic impact of hosting the Olympics regarding economic, social or urban issues at the local, regional and national level.

Table 2. Sample of studies on the socioeconomic impact of hosting the Summer Olympic Games

\begin{tabular}{|c|c|c|}
\hline Author(s) & Host city & Selected conclusions \\
\hline (Brunet 1995) & $\begin{array}{l}\text { Barcelona } \\
1992\end{array}$ & $\begin{array}{l}\text { - Increase in foreign direct and indirect investments in the } \\
\text { city as well as complex infrastructural transformation and } \\
\text { urban regeneration. }\end{array}$ \\
\hline $\begin{array}{l}\text { (Hotchkiss et al. } \\
\text { 2003) }\end{array}$ & Atlanta 1996 & $\begin{array}{l}\text { - The } 1996 \text { Summer Olympic Games boosted employment, } \\
\text { but no wage gains, in counties hosting Olympic venues } \\
\text { and counties near Olympic venues, when compared to the } \\
\text { economic performance of 1985-1993 and 1994-2000. }\end{array}$ \\
\hline $\begin{array}{l}\text { (Kasimati \& Daw- } \\
\text { son 2009) }\end{array}$ & Athens 2004 & $\begin{array}{l}\text { The Olympic Games had a positive impact on the Greek } \\
\text { economy; for the period } 1997-2005 \text {, the Games boosted } \\
\text { economic activity by around } 1.3 \% \text { of GDP per year, while } \\
\text { unemployment fell by } 1.9 \% \text { per year. }\end{array}$ \\
\hline $\begin{array}{l}\text { (Kissoudi 2008, } \\
\text { 2010) }\end{array}$ & Athens 2004 & $\begin{array}{l}\text { Athens acquired a modern transport infrastructure, reno- } \\
\text { vated the city centre, and there were many other upgrades. } \\
\text { However, the post-Olympic era was characterised by } \\
\text { several missed opportunities, mainly related to underused } \\
\text { and abandoned facilities, impeded by bureaucracy and } \\
\text { lack of long-term planning strategy to effectively exploit } \\
\text { sports venues. }\end{array}$ \\
\hline $\begin{array}{l}\text { (Zhang \& Zhao } \\
\text { 2007) }\end{array}$ & Beijing 2008 & $\begin{array}{l}\text { The authors estimated that from } 2002 \text { to } 2007 \text {, Olym- } \\
\text { pic-related investments added } 2.02 \%, 0.23 \% \text { and } 0.09 \% \\
\text { annually to gross regional products of Beijing, its neigh- } \\
\text { bouring areas and the rest of China, respectively. }\end{array}$ \\
\hline $\begin{array}{l}\text { (University of } \\
\text { East London } \\
\text { 2015) }\end{array}$ & London 2012 & $\begin{array}{l}\text { Selection of findings: } \\
\text { - The area in and around the Olympic Park underwent } \\
\text { extensive transformation and regeneration, } \\
\text { - Poverty and social exclusion rates were reduced in the six } \\
\text { host boroughs*, in part due to the legacy effect, } \\
\text { - Significant positive impact on the economic activity of } \\
\text { disabled people in the host boroughs. }\end{array}$ \\
\hline
\end{tabular}

2 These six recommendations are: 1) Shape the bidding process as an invitation; 2) Evaluate bid cities by assessing key opportunities and risks; 3) Reduce the cost of bidding; 4) Include sustainability in all aspects of the Olympic Games; 12) Reduce the cost and reinforce the flexibility of Olympic Games management; 13) Maximise synergies with Olympic Movement stakeholders (IOC 2018, p. 3). 


\begin{tabular}{lll}
\hline $\begin{array}{l}\text { (Dolan et al. } \\
\text { 2019) }\end{array}$ & London 2012 & $\begin{array}{l}\text { - } \\
\text { Hosting the event fostered a rise in the life satisfaction } \\
\text { of London residents, particularly around the opening and } \\
\text { closing ceremonies, but the authors did not find strong } \\
\text { evidence for legacy effects in the long-term. }\end{array}$ \\
\hline (Rocha et al. & $\begin{array}{l}\text { Rio de Janeiro } \\
2018)\end{array}$ & $\begin{array}{l}\text { By using the synthetic control method, the study proves } \\
\text { that the Games delayed and mitigated the effects of the } \\
\text { severe national macroeconomic crisis on Rio's GDP per } \\
\text { capita. Furthermore, the results indicate that there were } \\
\text { substantial increasing positive effects from 2012 to 2015, } \\
\text { for both municipal and metropolitan levels. }\end{array}$ \\
& Rio de Janeiro & $\begin{array}{l}\text { Throughout the preparations for the Games, several neg- } \\
\text { ative social actions took place, such as violent displace- } \\
\text { ment, forced evictions, the illegal destruction of private } \\
\text { property, and it also caused homelessness. }\end{array}$ \\
\hline
\end{tabular}

* Barking \& Dagenham, Greenwich, Hackney, Newham, Tower Hamlets and Waltham Forest.

Source: own work based on Brunet 1995; Crout 2018; Dolan et al. 2019; Hotchkiss et al. 2003; Kasimati \& Dawson 2009; Kissoudi 2008, 2010; Rocha et al. 2018; University of East London 2015; Zhang \& Zhao 2007.

\section{The Olympic Games as a catalyst for East London's development? A critical evaluation}

Legacy, impact, regeneration, renewal and strategy are just a few of the keywords to understand the rationale behind the idea to bid for the 2012 Summer Olympic Games of London's authorities and officials. The London Olympic bid embraced a broad vision of how to use the Olympics to develop the six most neglected host boroughs in East London. In the final candidate stage for the 2012 Olympics, London competed with Paris, Madrid, Moscow and New York - all with the status of global metropolises with strategic importance for the world economy. The concept of London's bid strongly emphasised the role of the Olympic event in transforming East London, and it was included in the city's spatial development strategy, namely The London Plan, issued in 2004. This document clearly stated that staging the Olympics was aimed at providing a catalyst for change and regeneration in this part of London, especially in terms of infrastructural and transport major improvements (Mayor of London 2004).

It is important to provide a brief historical and socioeconomic context of East London to explain why this part of the UK capital was selected to experience such a multifaceted urban change. Before the 1970s, East London was a manufacturing and industrial centre, with the city's docklands home to the working-class. Between the 1970s and 1980s, the authorities implemented political and economic reforms that led to a collapse on the labour market, and consequently, to high unemployment (Zimbalist 2016, p. 114). In the late 1980s, urban policies to regenerate this area were established, such as the Canary Wharf project. Despite the substantial 
efforts made to reinvigorate this area, a higher level of socioeconomic deprivation and exclusion among the relatively young local population, as well as lack of public transportation links to the city centre, prevailed (Zimbalist 2016, p. 114). London's Olympic legacy agenda promised to resolve most of these issues.

The Growth Boroughs Partnership is one of the initiatives established to trace the legacy outcomes of the 2012 London Games. Established in 2006 (formerly as the Host Boroughs Partnership), it is a collective unity between the six host boroughs created to maximise the benefits and minimise the disadvantages from the Olympic Games. Its framework is concentrated on delivering convergence within the UK capital, with the following main goal: "Within 20 years the communities who host the 2012 Games will have the same social and economic chances as their neighbours across London" and underlying principle aimed at "reducing the inequality gap in outcomes between disadvantaged groups and social classes with the average for London"' (London's Growth Boroughs, n.d., p. 2). According to the most recent Convergence Annual Report from 2015-2016, the set of indicators applied to monitor the state of convergence (in this article, the author selected 8 of the total 21 indicators) presents a rather mixed picture of improvement in the six host boroughs as summarised in Table 3 below.

Table 3. Selected Convergence Indicators status 2009-2015

\begin{tabular}{|c|c|c|c|c|}
\hline Indicator & Gap 2009 & Gap 2015 & 2020 Target & Status 2009-2015 \\
\hline $\begin{array}{l}\text { Employment rate } \\
\text { - aged 16-64 }\end{array}$ & 5.3 & 3.8 & $\begin{array}{l}\text { Narrow the gap } \\
\text { to } 2.5 \%\end{array}$ & $\begin{array}{l}\text { On track to meet the } \\
2020 \text { target }\end{array}$ \\
\hline Unemployment rate & 2.9 & 2.3 & $\begin{array}{l}\text { Narrow the gap } \\
\text { to } 1.4 \%\end{array}$ & \multirow{3}{*}{$\begin{array}{l}\text { Improvement on the } \\
\text { baseline but not on } \\
\text { a trajectory to achieve } \\
\text { the } 2020 \text { target, either } \\
\text { because improvement } \\
\text { from the baseline is too } \\
\text { marginal or the } 2015 \\
\text { performance is worse } \\
\text { than that in } 2014\end{array}$} \\
\hline $\begin{array}{l}\text { Percentage of work- } \\
\text { ing-age population } \\
\text { with no qualifications }\end{array}$ & 5.4 & 3.6 & $\begin{array}{l}\text { Narrow the gap } \\
\text { to } 1.5 \%\end{array}$ & \\
\hline $\begin{array}{l}\text { Working-age popu- } \\
\text { lation qualified to at } \\
\text { least Level } 4\end{array}$ & 7.5 & 6.7 & $\begin{array}{l}\text { Narrow the gap } \\
\text { to } 3.5 \%\end{array}$ & \\
\hline $\begin{array}{l}\text { Median earnings for } \\
\text { full-time workers } \\
\text { living in the area }\end{array}$ & 6.3 & 7.3 & $\begin{array}{l}\text { Narrow the gap } \\
\text { to } 3 \%\end{array}$ & \multirow{2}{*}{$\begin{array}{l}\text { Gap identical or } \\
\text { widened since the } \\
\text { baseline year }\end{array}$} \\
\hline Job Density & 0.26 & 0.26 & $\begin{array}{l}\text { Narrow the gap } \\
\text { to } 0.2\end{array}$ & \\
\hline $\begin{array}{l}\text { Recommended Adult } \\
\text { Activity ( } 3 \text { times } 30 \\
\text { mins per week) }\end{array}$ & 1.4 & 2.7 & $\begin{array}{l}\text { Narrow the gap } \\
\text { to } 1 \%\end{array}$ & $\begin{array}{l}\text { Not on track - in- } \\
\text { creasing }\end{array}$ \\
\hline $\begin{array}{l}\text { Violent crime levels } \\
\text { (Violence against } \\
\text { the person, per } 1000 \\
\text { population) }\end{array}$ & $\begin{array}{c}4.2 \\
(2009 / 2010)\end{array}$ & $\begin{array}{c}3.4 \\
(2015 / 2016)\end{array}$ & $\begin{array}{l}\text { To narrow the } \\
\text { gap to } 2 \%\end{array}$ & $\begin{array}{l}\text { Indicator worse than } \\
2014\end{array}$ \\
\hline
\end{tabular}

Source: adapted from London's Growth Boroughs, (n.d.). 
There are many examples of durable legacies from the London Games. Located in Stratford, ${ }^{3}$ the Olympic Park (after the Olympics it was renamed the Queen Elizabeth II Olympic Park) and the Olympic Village (now the East Village) can be regarded as flagship projects for urban regeneration in this part of the UK capital. The Olympic Park is an impressive and extensive multifunctional site, spreading across the Lower Lea Valley. The Park is free to visit and open to the public. Among the iconic architectural legacies is a tower-like sculpture, ArcelorMittal Orbit, which is a combination of contemporary art, a viewing platform and a tunnel slide. The (East) Olympic Village was converted into a residential area; however, the planned legacy regarding the amount of affordable social housing in this particular neighbourhood had been considerably reduced (Bernstock 2014). The former Press and Broadcast Centres for the 2012 Games now operate as an innovation campus for global and emerging businesses, universities, and research and creative institutions (London Legacy Development Corporation, n.d.).

The Games provided East London with broad improvements in the transport system connecting the area with the city centre. The issue of sustainability was also strongly highlighted in London's legacy planning (Gold \& Gold 2015). The Commission for a Sustainable London 2012, which monitored the sustainable practices throughout the Games, even proclaimed London 2012 the "most sustainable games ever" (DCMS 2013, p. 20). One of the legacy promises was to avoid white elephants; London tackled this recurrent problem associated with the Olympics by delivering a planning and design strategy spread over several years (Davis 2019). The current state of the major sports facilities in the Olympic Park is as follows (London Legacy Development Corporation, n.d.):

- The Main Stadium eventually found an end-user. It is home to West Ham United Football Club, but this deal came with high public expenditures (e.g. conversion costs of the main stadium to a football facility) and flawed model of the legacy plans concerning the stadium (Evans \& Edizel 2017; Horne \& Whannel 2020, pp. 82-85);

- The London Aquatics Centre was converted into a communal resource and is open to the public use with a payable entrance;

- The Copper Box Arena is a multisport indoor venue, open to the public;

- Lee Valley Hockey and Tennis Centre - available for public use, all year round;

- Lee Valley VeloPark - a venue for track cycling, road racing, BMX or mountain biking, open to the public.

${ }^{3}$ A district in the East End of London, in the London Borough of Newham. 
Organising the Olympic Games also brought several troubling views on legacy promises versus their real implementation. Throughout the bidding, staging and legacy processes, many adverse effects occurred, especially affecting local communities and businesses, such as displacement experiences of lower-income East Londoners and the gentrification of East London (Watt 2013), small business exclusion in the tumult of Olympic planning and replacement by global and national businesses (Duignan 2019), inappropriate housing policy (Bernstock 2014; Bernstock \& Watt 2017), or unequal employment policy, where the skilled and educated residents of East London were ignored for professional job positions, providing evidence for the ineffectiveness of the Olympic Employment Programme (Vadiati 2020). In turn, Poynter (2017) presents an analysis of East London's post-Olympic economy arguing that the London legacy is more shaped by capital and financial turn than by promises made by succeeding governments (p. 48).

Undoubtedly, the London Olympics have visibly contributed to urban and transport development and left East London host boroughs with considerable tangible and intangible benefits. The site adjacent to the Olympic Park has markedly changed its character - from a neglected, post-industrial brownfield area to a regenerated urban space. However, the Olympic-related social and economic impacts observed in East London are ambiguous - mixing positive and negative ones. This inconsistency highlights the need for further research and analysis in this particular case.

\section{London vs. selected global cities. An empirical analysis of economic performance in the context of organising the Olympic Games}

As many global cities convey their interest in hosting the Olympic Games, it would be interesting to examine the economic performance of one host city against selected global cities within the adopted time span, which encompasses the preparation, organisation and legacy stages.

For the following analysis, data were collected from the Passport + Cities + Industrial database provided by Euromonitor International (2020). The final sample covers 12 global cities divided into three comparative groups by region (see Table 4), with which London was compared. The cities were selected based on their Alpha status given by the Globalization and World Cities (GaWC) classification (GaWC 2018). These metropolises are of great importance in terms of their economic status and strategic position in the global economy, positioning them as an appropriate reference group compared to London. However, it should be noted that the results of this analysis might be affected by the fact that some 
cities organised sports mega-events in the adopted time span or will be hosting such event in the near future. Beijing was the host of the 2008 Summer Olympic Games, and it is already preparing for the 2022 Winter Olympic Games; Moscow was one of the host cities of the 2018 Football World Cup; Tokyo is the host for the 2020 Summer Olympics; ${ }^{4}$ Paris was one of the host cities during the UEFA Euro 2016, and it will be staging the 2024 Summer Olympic Games; Los Angeles is the host of the 2028 Summer Olympic Games.

Table 4. Cities and reference groups by region

\begin{tabular}{ll}
\hline \multicolumn{1}{c}{ Region } & \multicolumn{1}{c}{ Cities } \\
\hline Asia & Beijing, Shanghai, Tokyo, Seoul \\
\hline Europe & Madrid, Moscow, Paris \\
\hline North America and Australia & Chicago, Los Angeles, New York, Toronto, Sydney \\
\hline
\end{tabular}

Source: author's own work.

This study applies two standard macroeconomic indicators: real GDP growth rate and unemployment rate (all expressed in percentage) to demonstrate the dynamics of change in the context of organising the Olympic Games. These indicators are commonly used in measuring the economic impact of global sports mega-events as they are determined by induced economic activity through, among others, sports and non-sports infrastructural investments and tourist traffic. The period spans 2005-2018 and covers three phases (see Figure 1). The beginning of time range is dictated by the selection of London as the host of the 2012 Olympics, and the end is determined by maximum data availability. The empirical section of this paper is, to some extent, based on methods used by Zawadzki (2017). The first part illustrates London's economic performance against selected cities according to a particular region. In the second part, the average deviations of real GDP growth rates and unemployment rates between London and the comparative groups were estimated.

Figure 1. Time intervals adopted in research

Pre-Games Phase (t-7; t-1)

from 2005 to 2011

\section{O} O

Games Phase (t) 2012
Post-Games Phase $(\mathrm{t}+1 ; \mathrm{t}+6)$

from 2013 to 2018

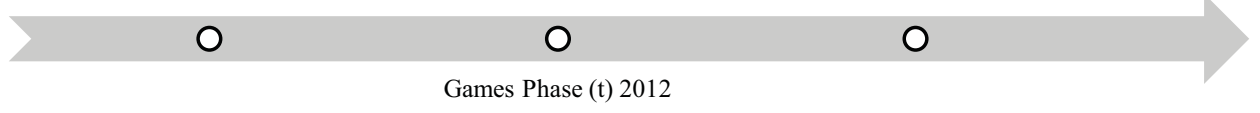

Source: author's own work.

${ }^{4}$ Due to the COVID-19 pandemic, the 2020 Tokyo Olympic Games have been postponed and will now be held between 23 July and 8 August 2021 (IOC 2020). However, the emblem Tokyo 2020 remains to avoid additional rebranding costs (Golob 2020). 
Figure 2. Real GDP growth rate: London vs. global cities from comparative groups

\section{Real GDP Growth Rate: London vs. European Cities}

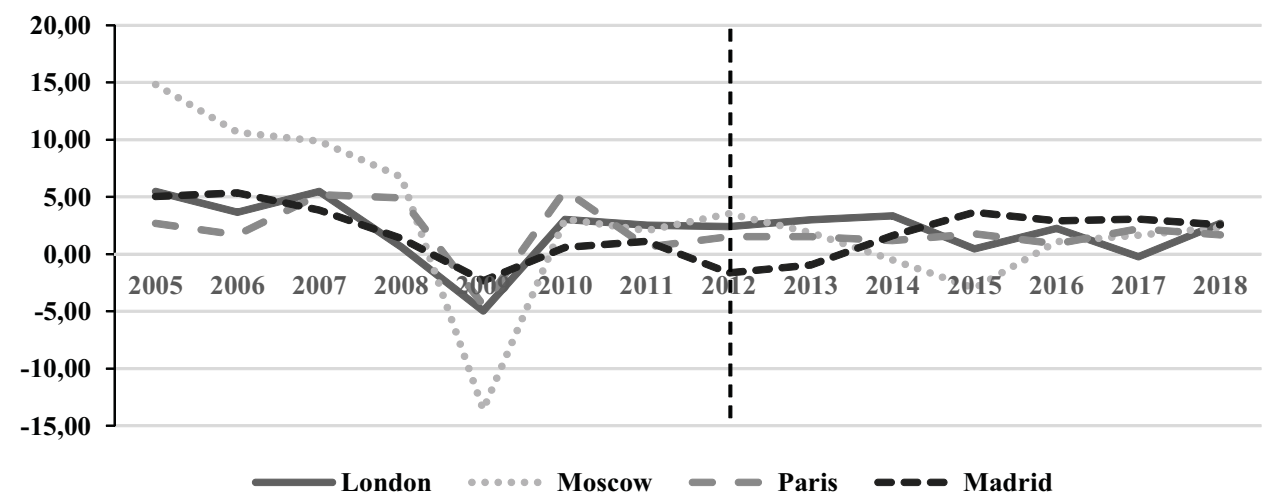

Real GDP Growth Rate London vs. North American and Australian Cities

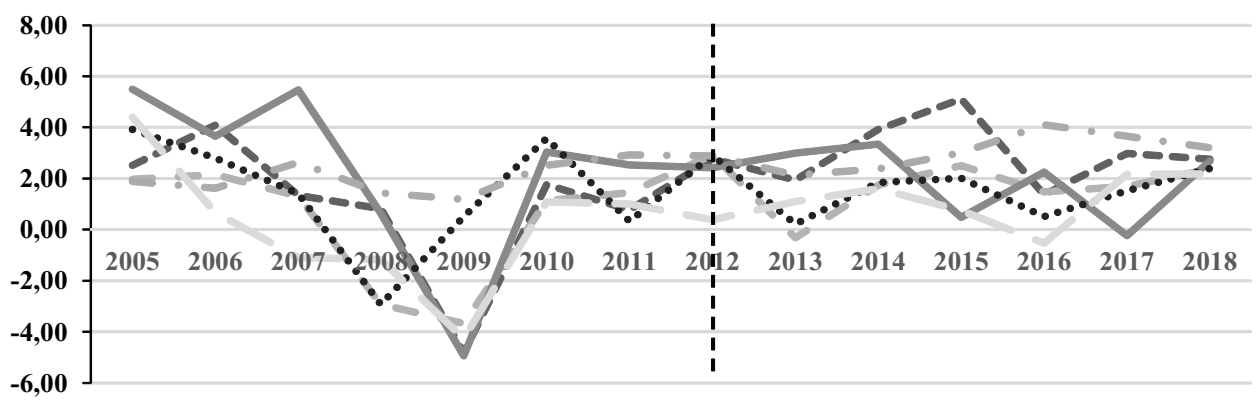

$$
\begin{aligned}
& \text { - - Los Angeles - Chicago London } \\
& \text {...... New York - Toronto - - - Sydney }
\end{aligned}
$$

Real GDP Growth Rate: London vs. Asian Cities

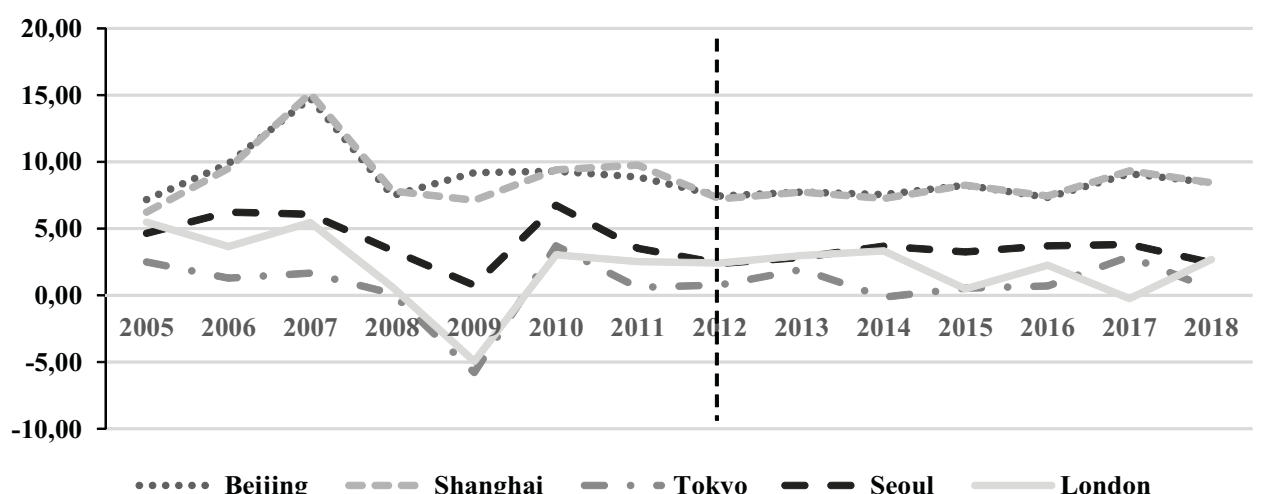

Source: author's own work based on Euromonitor International (2020) database (accessed: 16.06.2020). 
Figure 3. Unemployment rate: London vs. global cities from comparative groups

\section{Unemployment Rate: London vs. European Cities}

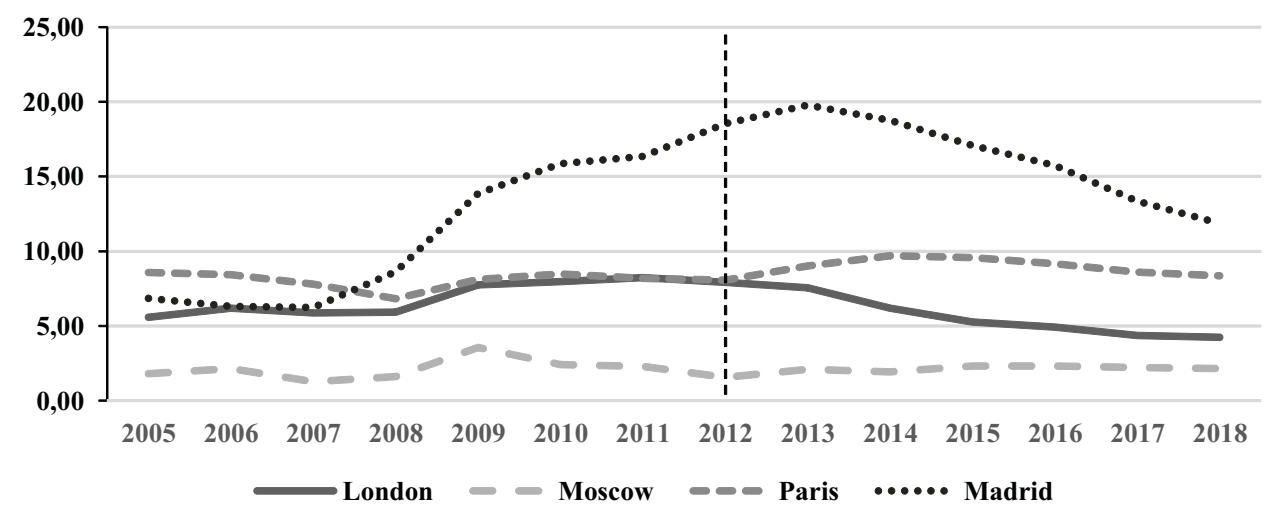

Unemployment Rate: London vs. North America and Australian Cities

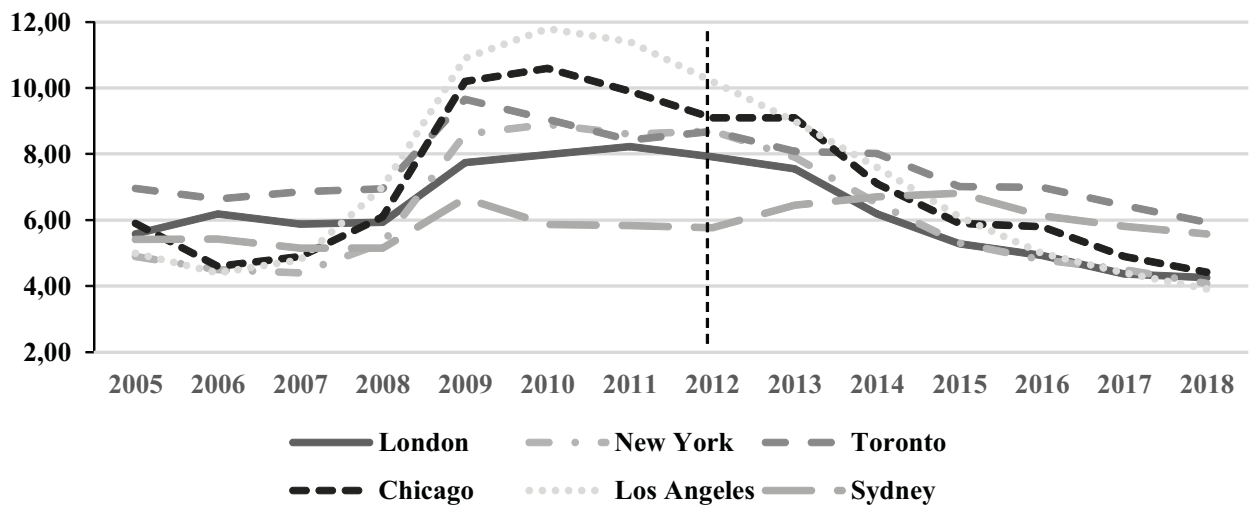

Unemployment Rate: London vs. Asian Cities

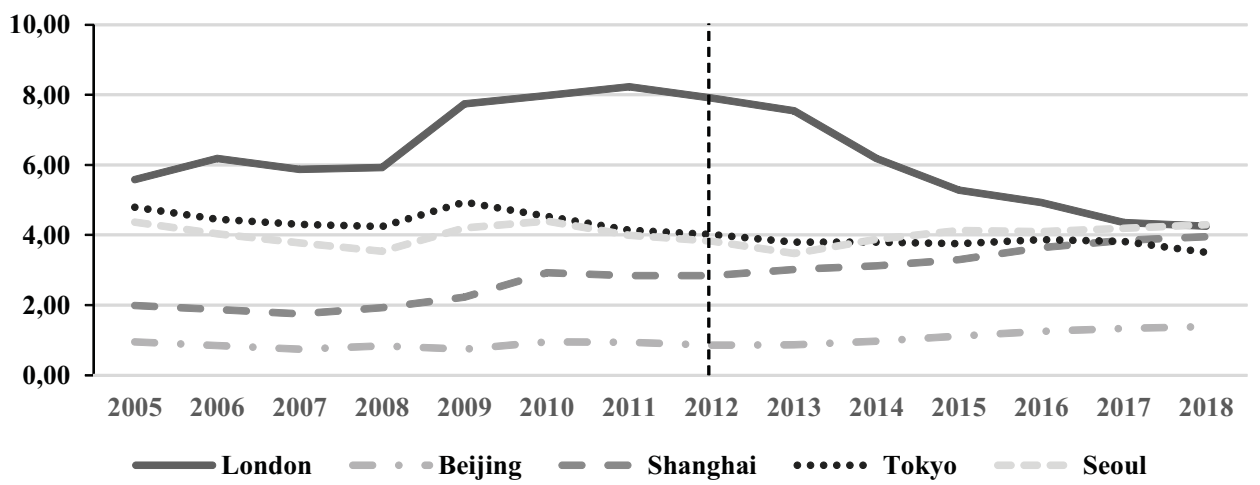

Source: author's own work based on Euromonitor International (2020) database (accessed: 16.06.2020). 
In order to observe the dynamics of economic variables applied in this research, several figures were drawn. The real GDP growth rate is the first variable whose dynamics is depicted throughout the fixed time frame (Figure 2). In 2012, when the Games took place, London's real GDP growth rate stabilised after the 20072009 global financial crisis, reaching approximately 3\% between 2013 and 2014. According to the figures, the financial and economic crisis affected almost all cities; however, Asian cities (except Tokyo) noted positive real GDP growth rates and, to some extent, mitigated negative effects. Cities from the so-called Global North and Sydney noted a very similar trend in the fluctuations of real GDP growth rate.

Unemployment rate (expressed as a \% of the economically active population) is the second indicator used to examine London's economic performance against selected global cities. As shown in the figures, the UK capital noted an increase in the unemployment rate between 2008 and 2013, presumably as a consequence of the global economic slowdown in the production and service sectors, which reached its peak value in 2011, one year before the Olympics. Within the next few years, London's labour market recovered from the recession with an unemployment rate of around $4.3 \%$ in 2018.

Table 5. Average deviations between London and comparative groups (in \%)

\begin{tabular}{lccccccc}
\hline \multicolumn{1}{c}{$\begin{array}{c}\text { Games' } \\
\text { Phase }\end{array}$} & $\begin{array}{c}\text { London } \\
\text { (Host } \\
\text { City) }\end{array}$ & $\begin{array}{c}\text { European } \\
\text { cities }\end{array}$ & $\begin{array}{c}\text { Average } \\
\text { deviation } \\
\text { from host }\end{array}$ & $\begin{array}{c}\text { North } \\
\text { American } \\
\text { and Austra- } \\
\text { lian cities }\end{array}$ & $\begin{array}{c}\text { Average } \\
\text { deviation } \\
\text { from host }\end{array}$ & $\begin{array}{c}\text { Asian } \\
\text { cities }\end{array}$ & $\begin{array}{c}\text { Average } \\
\text { deviation } \\
\text { from host }\end{array}$ \\
\hline $\begin{array}{l}\text { Pre-Games } \\
\text { Phase }\end{array}$ & 2.27 & 3.09 & -0.82 & 0.92 & 1.35 & 5.97 & -3.70 \\
\hline $\begin{array}{l}\text { Games } \\
\text { Phase }\end{array}$ & 2.42 & 1.15 & 1.27 & 2.38 & 0.04 & 4.47 & -2.05 \\
\hline $\begin{array}{l}\text { Post-Ga- } \\
\text { mes Phase }\end{array}$ & 1.92 & 1.43 & 0.49 & 2.06 & -0.14 & 5.14 & -3.22 \\
\hline $\begin{array}{l}\text { Pre-Games } \\
\text { Phase }\end{array}$ & 6.79 & 6.93 & -0.14 & 7.05 & -0.26 & 2.90 & 3.89 \\
\hline $\begin{array}{l}\text { Games } \\
\text { Phase }\end{array}$ & 7.91 & 9.39 & -1.48 & 8.50 & -0.59 & 2.89 & 5.02 \\
\hline $\begin{array}{l}\text { Post-Ga- } \\
\text { mes Phase }\end{array}$ & 5.43 & 9.11 & -3.68 & 6.21 & -0.78 & 3.10 & 2.33 \\
\hline
\end{tabular}

Source: author's own elaboration based on Euromonitor International (2020) database (accessed: 16.06.2020).

The following empirical strategy is based on calculating the average deviations of economic indicators between London and the comparative groups of cities. For London and each group, the mean values of the indicators were calculated in accordance with established the time phases presented in Figure 1. Having obtained the 
results, London was compared with three reference groups of cities by estimating the average deviations of economic indicators (see Table 5). In the case of the real GDP growth rate, positive/negative deviations mean, respectively, the host city's better/ worse economic performance, whereas, for the unemployment rate, negative average deviations refer to London's better economic performance, as the rate is lower than in the reference group. In this case, Asian cities outperformed London, with higher average real GDP growth rates and lower average unemployment rates throughout all phases.

\section{Concluding remarks}

The analysis has shown that during the Pre-Games, Games and Post-Games phases, the dynamics of changes in economic indicators observed in London, largely behaved in a similar way compared with European, North American and Australian cities. The pace of economic growth among Asian global cities outperformed London and the other reference groups. Similar conclusion can be drawn referring to the situation on the labour market expressed by the unemployment rate. Several similarities occurred in advanced economies during 2007-2009 global financial crisis when they noted significant declines in selected macroeconomic indicators. The results of the empirical part of this study do not allow us to unambiguously confirm the hypothesis that the Olympic Games in London contributed significantly - positively or negatively - to its economic performance against the backdrop of selected global cities. Furthermore, there are many different factors and traits of the economy that determine economic performance, such as institutional or cultural aspects not included in this study, thus making it difficult to draw more robust conclusions. Nonetheless, this research allows us to compare global cities in terms of their trajectory of economic development, given the Olympic context.

Among the key motivations for staging the Olympic Games is an improvement in the image of a city and its promotion on the international stage, presenting it as a dynamic and attractive place to live, visit or invest in. It is generally believed that the organisation of the Olympic Games in London was hailed a success; the city delivered a memorable sports festival, widely acclaimed by the global public. From an event perspective, the domestic English population also considered the Games a fruitful enterprise (Kenyon \& Bodet 2018). Jacques Rogge, the IOC President at the time, praised the London organisers for holding a "fabulous" Olympics, and for creating great conditions and atmosphere for athletes to "make history" (BBC 2012). Given the fact that sport is an important part of the British national identity, one might have expected that the Olympic event would be a festive and organisational triumph with great sporting successes and results, including for the British athletes. Undoubtedly, staging the Olympic Games reinforced London's position and image on the map of global sports capitals. 
Further conclusions can be drawn based on the wide-ranging literature review examining various types of legacy in the UK capital, especially with an emphasis on the East London boroughs. Some of them prove that the Olympic event brought substantial socioeconomic changes (e.g. DCMS 2013; HM Government \& Mayor of London 2016), while others provide a critical view; for instance, Zimbalist (2016, p. 123) points out that the organising the Olympics enabled particular groups to gain benefits by transferring public money to private sectors, which led to wealth being relocated rather than created. Undoubtedly, the London Olympic bid was built around an ambitious and extensive legacy framework based on far-reaching urban regeneration, infrastructural and transport developments, and social and economic boost - all aimed at narrowing the gap between London's poorest areas and the rest of the city. Some of the legacy goals have been achieved, among others, significant transport improvements, creating a new space for business and education, or providing a general beautification and redesign. However, a broad set of urban interventions stimulated by the Olympics also generated negative effects, such as displacements, unsuitable housing policy, or the gentrification process which, caused much controversy in the urban and social space. As a result, it is very difficult to accurately evaluate the Olympic legacy, as it depends on the point of view represented by directly affected groups - local communities, residents, local entrepreneurs, authorities or big business.

Without a doubt, London's legacy strategy established new standards for future Olympic cities for how to use the organisation of the Games as a tool for urban and socioeconomic development in the most disadvantaged areas of a city, as well as to boost its image as a global sports capital. The forthcoming hosts of the Olympic Games are truly global and developed cities - Tokyo 2020 (2021), Paris 2024 and Los Angeles 2028. All have a high-level sporting base, numerous readyto-use venues, transport infrastructure, and they are filled with tourist attractions and admiration for sport. These hosts already promise to deliver a long-lasting and multifaceted legacy. However, time will tell what the results of these promises will be.

\section{Bibliography}

Andranovich, G., Burbank, M.J., \& Heying, C.H. (2001), Olympic Cities: Lessons Learned from Mega-Event Politics, Journal of Urban Affairs, 23(2), $113-131$.

BBC. (2012, August 12), London 2012: IOC chief Jacques Rogge 'very happy' with Games, https://www.bbc.com/news/uk-19233495 (accessed: 18 June 2020). 
Bernstock, P. (2014), Olympic Housing: A Critical Review of London 2012's Legacy, Routledge, London and New York.

Bernstock, P., \& Watt, P. (2017), Legacy for Whom? Housing in Post-Olympic East London, [in:] P. Cohen \& P. Watt (Eds.), London 2012 and the Post-Olympic City: A Hollow Legacy? (pp. 91-138), Palgrave Macmillan, London.

Brunet, F. (1995), An economic analysis of the Barcelona'92 Olympic Games: Resources, financing and impacts, Centre d'Estudis Olímpics UAB, http:// olympicstudies.uab.es/pdf/wp030_eng.pdf (accessed: 26 August 2019).

Cashman, R. (2006), The Bitter-sweet Awakening: The Legacy of the Sydney 2000 Olympic Games, Walla Walla Press, Sydney.

Chappelet, J.-L. (2012), Mega Sporting Event Legacies: A Multifaceted Concept. Papeles de Europa, 0(25), 76-86.

Chen, Y., Qu, L., \& Spaans, M. (2013), Framing the Long-Term Impact of Mega-Event Strategies on the Development of Olympic Host Cities, Planning Practice and Research, 28(3), 340-359.

Crout, L.C. (2018), Forced Evictions, Homelessness, and Destruction: Summer 'Games'? Olympic Violations of the Right to Adequate Housing in Rio de Janeiro, Notre Dame Journal of International \& Comparative Law, 8(1), https:// scholarship.law.nd.edu/ndjicl/vol8/iss1/7 (accessed: 19 November 2019).

Davis, J. (2019), Avoiding white elephants? The planning and design of London's 2012 Olympic and Paralympic venues, 2002-2018, Planning Perspectives, $1-22$.

DCMS. (2013). Report 5: Post-Games Evaluation. Meta-Evaluation of the Impacts and Legacy of the London 2012 Olympic Games and Paralympic Games [Summary Report], Department for Culture Media \& Sport, https://assets. publishing.service.gov.uk/government/uploads/system/uploads/attachment data/file/224181/1188-B_Meta_Evaluation.pdf (accessed: 3 March 2016).

Dolan, P., Kavetsos, G., Krekel, C., Mavridis, D., Metcalfe, R., Senik, C., Szymanski, S., \& Ziebarth, N.R. (2019), Quantifying the intangible impact of the Olympics using subjective well-being data, Journal of Public Economics, $177,1-14$.

Duignan, M.B. (2019), London's local Olympic legacy: Small business displacement, 'clone town' effect and the production of 'urban blandscapes', Journal of Place Management and Development, 12(2), 142-163.

Essex, S., \& Chalkley, B. (1998), Olympic Games: Catalyst of urban change, Leisure Studies, 17(3), 187-206.

Euromonitor International. (2020), Passport + Cities + Industrial database, https://go.euromonitor.com/passport.html (accessed: 16 June 2020).

Evans, G., \& Edizel, Ö. (2017), London 2012, [in:] J. Gold \& M. Gold (Eds.), Olympic Cities. Routledge, London and New York, NY. 
Furrer, P. (2002), Sustainable Olympic Games, Bollettino Della Società Geografica Italiana, VII(4), 31.

GaWC. (2018), The World According to GaWC 2018, Globalization and World Cities Research Network, https://www.lboro.ac.uk/gawc/world2018t.html (accessed: 2 July 2020).

Gold, J.R., \& Gold, M.M. (2015), Framing the future: Sustainability, legacy and the 2012 London Games, [in:] R. Holt \& D. Ruta (Eds.), Routledge handbook of sport and legacy: Meeting the challenge of major sports events (1st Edition, pp. 142-158), Routledge, London and New York.

Golob, B. (2020, April 1), Postponed Olympics retains 2020 naming, branding, Transform magazine, https://www.transformmagazine.net/articles/2020/postponed-olympics-retains-2020-naming-branding/ (accessed: 3 July 2020).

Gratton, C., \& Preuss, H. (2008), Maximizing Olympic Impacts by Building Up Legacies, The International Journal of the History of Sport, 25(14), 1922-1938.

HM Government, \& Mayor of London. (2016), Inspired by 2012: The legacy from the Olympic and Paralympic Games [Fourth annual report - summer 2016], https://assets.publishing.service.gov.uk/government/uploads/system/ uploads/attachment_data/file/544197/1776-E_Legacy_Report_2016_ACCESSIBLE.pdf (accessed: 3 July 2020).

Horne, J., \& Whannel, G. (2020), Understanding the Olympics (Third Edition). Routledge, London.

Hotchkiss, J.L., Moore, R.E., \& Zobay, S.M. (2003), Impact of the 1996 Summer Olympic Games on Employment and Wages in Georgia, Southern Economic Journal, 69(3), 691.

IOC. (2014), Olympic Agenda 2020: 20 + 20 Recommendations, International Olympic Committee, https://stillmed.olympic.org/Documents/Olympic Agenda_2020/Olympic_Agenda_2020-20-20_Recommendations-ENG.pdf (accessed: 1 July 2020).

IOC. (2017), Legacy Strategic Approach: Moving Forward, IOC, https://www. olympic.org/ /media/Document\%20Library/OlympicOrg/Documents/ Olympic-Legacy/IOC_Legacy_Strategy_Full_version.pdf?la=en (accessed: 24 September 2018).

IOC. (2018), Olympic Agenda 2020. Olympic Games: The New Norm [Report by the Executive Steering Committee for Olympic Games Delivery], International Olympic Committee, https://stillmed.olympic.org/media/Document $\% 20$ Library/OlympicOrg/News/2018/02/2018-02-06-Olympic-Games-theNew-Norm-Report.pdf\#_ga=2.128045071.2055400892.15937244961399807603.1588276354 (accessed: 3 July 2018).

IOC. (2020, March 30), IOC, IPC, Tokyo 2020 Organising Committee and Tokyo Metropolitan Government announce new dates for the Olympic and Paralympic 
Games Tokyo 2020, https://www.olympic.org/news/ioc-ipc-tokyo-2020-organising-committee-and-tokyo-metropolitan-government-announce-new-dates-for-the-olympic-and-paralympic-games-tokyo-2020 (accessed: 3 July 2020).

Kasimati, E. (2003), Economic aspects and the Summer Olympics: A review of related research, International Journal of Tourism Research, 5(6), 433-444.

Kasimati, E., \& Dawson, P. (2009), Assessing the impact of the 2004 Olympic Games on the Greek economy: A small macroeconometric model, Economic Modelling, 26(1), 139-146.

Kenyon, J.A., \& Bodet, G. (2018), Exploring the domestic relationship between mega-events and destination image: The image impact of hosting the 2012 Olympic Games for the city of London, Sport Management Review, 21(3), 232-249.

Kissoudi, P. (2008), The Athens Olympics: Optimistic Legacies - Post-Olympic Assets and the Struggle for their Realisation, The International Journal of the History of Sport, 25(14), 1972-1990.

Kissoudi, P. (2010), Athens' Post-Olympic Aspirations and the Extent of their Realisation, The International Journal of the History of Sport, 27(16-18), 2780-2797.

London Legacy Development Corporation. (n.d.), Queen Elizabeth Olympic Park, https://www.queenelizabetholympicpark.co.uk/the-park (accessed: 19 June 2020).

London's Growth Boroughs. (n.d.), Convergence Annual Report 2015-2016, London's Growth Boroughs, https://static1.squarespace.com/static/50b4ab77e4b0214dc1f631e9/t/58977d7b29687ff9f4cbd575/1486323077253/Convergence+Annual+Report+15-16+fin.pdf (accessed: 4 February 2019).

Mayor of London. (2004), The London Plan. Spatial Development Strategy for Greater London, Greater London Authority, https://www.london.gov.uk/ sites/default/files/the_london_plan_2004.pdf (accessed: 1 May 2020).

Open Economics \& CEIS-Tor Vergata. (2016), Economic Impact Assessment of the Rome 2024 Olympic and Paralympic Games. Technical Report.

Poynter, G. (2017), East London's Post-Olympic Economy, [in:] P. Cohen \& P. Watt (Eds.), London 2012 and the Post-Olympics City (pp. 27-51), Palgrave Macmillan, London.

Preuss, H. (2007), The Conceptualisation and Measurement of Mega Sport Event Legacies, Journal of Sport \& Tourism, 12(3-4), 207-228.

Rocha, G., Araújo, H.E., \& Machado de Codes, A.L. (2018), Impactos Econômicos dos Jogos Rio 2016 no Município e na Região Metropolitana do Rio de Janeiro (No. 2438), Brazil Institute for Applied Economic Research (IPEA), https://www.econstor.eu/bitstream/10419/211389/1/1046127535.pdf (accessed: 4 January 2020). 
Roche, M. (2017), Mega-events and Social Change: Spectacle, Legacy and Public Culture, Manchester University Press, Manchester.

Sassen, S. (2005), The Global City: Introducing a Concept, Brown Journal of World Affairs, 11(2), 27-43.

Scandizzo, P.L., \& Pierleoni, M.R. (2018), Assessing the Olympic Games: The Economic impact and beyond, Journal of Economic Surveys, 32(3), 649-682.

Shoval, N. (2002), A New Phase in the Competition for the Olympic Gold: The London and New York Bids for the 2012 Games, Journal of Urban Affairs, 24(5), 583-599.

Tolzmann, M.C. (2014), Global localities: Olympic bidding as a case study in globalisation, Sport in Society, 17(5), 593-608.

University of East London. (2015), Olympic Games Impact Study - London 2012 Post-Games Report: December 2015, University of East London, London.

Vadiati, N. (2020), The Employment Legacy of the 2012 Olympic Games: A Case Study of East London, Springer Singapore.

Watt, P. (2013), 'It's not for us': Regeneration, the 2012 Olympics and the gentrification of East London, City, 17(1), 99-118.

Zawadzki, K. (2017), Ekonomiczne efekty organizacji wielkoformatowych wydarzeń sportowych, Wydawnictwo Politechniki Gdańskiej, Gdańsk.

Zhang, Y., \& Zhao, K. (2007), Impact of Beijing Olympic-related Investments on Regional Economic Growth of China: Interregional Input-Output Approach, Asian Economic Journal, 21(3), 261-282.

Zimbalist, A. (2016), Circus Maximus: The Economic Gamble Behind Hosting the Olympics and the World Cup (2nd Edition), Brookings Institution Press, Washington DC, United States.

\section{Summary}

The highly competitive global environment reinforces the trend to seek new investment opportunities that have various impacts on the local economy, and staging the Olympic Games is seen as one such example. The 2012 Summer Olympic Games in London have been widely discussed and investigated due to the very ambitious plans for socioeconomic and infrastructural development prompted by the Olympic legacy framework. Based on these observations, there are two main aims of this article. The first one is to evaluate London's post-event legacy based on a literature review. The second research goal is to assess London's economic performance compared with reference groups of global cities by using selected economic indicators. Both qualitative and quantitative methods were applied in this research, such as a critical literature review, a series of figures and tables with economic indicators and descriptive statistics. Based on the literature review 
and the author's own elaborations, it can be concluded that the Olympic legacy framework and the Games themselves fostered economic and urban development, especially in East London. However, positive impacts and legacies were intermingled with several adverse effects. In turn, a comparative analysis of economic performance between London as the host city and reference groups of global cities demonstrates that, in the adopted time intervals, the dynamics of changes in applied economic indicators is relatively quite similar in groups of European, North American and Australian cities. In contrast, Asian cities, as one reference group, outperformed London and other global cities for the vast majority of the adopted time span.

Keywords: Olympic Games, economic performance, global cities, dynamics

\section{Streszczenie}

Igrzyska olimpijskie a sytuacja gospodarcza miasta-gospodarza - przykład Londynu 2012 na tle wybranych miast globalnych

Wysoce konkurencyjna gospodarka globalna wzmaga tendencję poszukiwania nowych możliwości inwestycyjnych, mogących wygenerować impulsy rozwojowe w przestrzeni miejskiej. Jednym z tego typu przykładów jest organizacja igrzysk olimpijskich, która postrzegana jest jako ogromny projekt inwestycyjny realizowany w miastach-gospodarzach. Letnie Igrzyska Olimpijskie 2012 w Londynie były szeroko dyskutowane i analizowane, ze względu na bardzo ambitne plany rozwoju społeczno-gospodarczego i infrastrukturalnego dzięki organizacji wydarzenia. Na podstawie powyższych obserwacji, w artykule przyjęto dwa główne cele badawcze. Pierwszym z nich jest ocena dziedzictwa olimpijskiego w Londynie na podstawie krytycznego przeglądu literatury. Drugim celem badawczym jest ocena sytuacji gospodarczej Londynu jako olimpijskiego miasta-gospodarza na tle wybranych miast globalnych, opierając się na wybranych wskaźnikach ekonomicznych. W artykule zastosowano zarówno metody jakościowe, jak i ilościowe takie, jak krytyczny przegląd literatury oraz podstawowa statystyka opisowa zaprezentowana za pomocą serii wykresów oraz tabeli z uśrednionymi wskaźnikami ekonomicznymi jak stopa wzrostu PKB oraz stopa bezrobocia. Na podstawie przeglądu literatury i dokonanej analizy można stwierdzić, że plan wykorzystania organizacji Igrzysk Olimpijskich w Londynie oraz samo wydarzenie sprzyjały rozwojowi gospodarczemu oraz miejskiej regeneracji, w szczególności we wschodniej części miasta, jednakże pozytywnym skutkom towarzyszyły również negatywne efekty, m.in. w sferze społecznej i gospodarczej. $Z$ kolei komparatywna analiza sytuacji gospodarczej 
Londynu jako miasta-gospodarza i pozostałych miast globalnych stanowiących grupy porównawcze pokazała, że w przyjętym zakresie czasowym, dynamika zmian wybranych wskaźników ekonomicznych jest relatywnie podobna w grupie miast europejskich, Ameryki Północnej oraz Australii, podczas gdy miasta azjatyckie jako grupa porównawcza zanotowały względnie lepszą sytuację gospodarczą mierzoną przyjętymi wskaźnikami w przeważającej części zakresu czasowego 2005-2018.

Słowa kluczowe: igrzyska olimpijskie, wpływ ekonomiczny, miasta globalne, dynamika

JEL: R11, R58 